Article

\title{
Evaluating the Antibacterial Activity of MgO Nanoparticles Synthesized from Aqueous Leaf Extract
}

Jaison Jeevanandam ${ }^{1, *}$, Yen San Chan ${ }^{1}$, Michael K. Danquah ${ }^{2}$

1 Department of Chemical Engineering, Faculty of Engineering and Science, Curtin University, CDT 250, 98009 Miri, Sarawak, Malaysia

2 Chemical Engineering Department, University of Tennessee, Chattanooga, TN 37403, USA

* Correspondence: Jaison Jeevanandam, Email: jaison.jeevanandam@postgrad.curtin.edu.my; Tel.: +91-740-103-9626.

\section{ABSTRACT}

Foodborne pathogens especially bacteria cause a vast number of diseases which leads to a high mortality rate in humans. Conventional antibiotics have been employed in an attempt to eradicate these pathogens and this has led to the evolution of a multidrug resistant bacteria strain. Thus, a new genre of antibiotics is prepared by using nanoparticles as they show effective antibacterial capabilities. Biosynthesized nanoparticles are less toxic to humans as compared to chemically synthesized nanoparticles which are prepared using toxic precursors. They also exhibit enhanced antibacterial action along with the biomolecules that help in their formation. Among most metal oxides, magnesium oxide (MgO) nanoparticles show unique antibacterial properties due to their exclusive oxide vacancies and crystalline structure. The antibacterial activity of MgO nanoparticles synthesized using leaf extract is further enhanced by the presence of phytochemicals. The present work is a comparative study of the antibacterial activity of $\mathrm{MgO}$ nanoparticles synthesized using three different leaf extracts: (1) Amaranthus tricolor, (2) Amaranthus blitum and (3) Andrographis paniculata and their reaction towards Escherichia coli which is a gram negative, food borne pathogen. The results showed that the $\sim 8 \mathrm{~nm}$ spherical shaped MgO nanoparticles synthesized from $A$. blitum, exhibited the highest antibacterial activity at $60 \mu \mathrm{L}$ dosage. In addition, the effects of the characteristics of the MgO nanoparticles such as size, morphology, concentration, surface charge and phytochemicals on antibacterial mechanism were also discussed.

Published: 18 June 2019

Copyright (c) 2019 by the author(s). Licensee Hapres,

KEYWORDS: antibacterial activity; Escherichia coli; MgO nanoparticles; phytochemicals; reactive oxygen species

London, United Kingdom. This is an open access article distributed under the terms and conditions of Creative Commons Attribution 4.0 International License.

\section{INTRODUCTION}

In 2016, the World Health Organization (WHO) reported that 420,000 people died due to food borne diseases caused by several microbes and 
125,000 among them were children below age of 5 years [1]. It is well known from previous reports that bacteria is the most important micro-organism which can spread lethal food-borne diseases [2,3]. Conventionally, antibiotics are extensively used to eradicate these diseasecausing bactericides [4], which has led to the emergence of multidrug resistant bacterial strains in the long term [5,6]. Therefore, it is urgent to develop an enhanced antibacterial agent to deal with these multidrug resistant bacterial strains mediating the spread of food borne diseases. Recently, inorganic antibacterial agents have been studied extensively, due to their controlled reactive oxygen species (ROS) which suppresses the micro-organisms growth to effectively control pathogenic microorganisms [7-9]. It was reported that inorganic antibacterial agents showed improved safety and stability under high temperature treatments than organic antibiotics [10,11]. Inorganic nanoparticles, especially metal oxides are gaining attention in various industrial applications due to their ability to withstand harsh conditions [12,13], excellent antimicrobial activity $[14,15]$ and they are highly useful in many biomedical applications such as tissue engineering, diagnostics and therapeutics [16,17]. Inorganic metal oxide nanoparticles such as $\mathrm{ZnO}$ [18], $\mathrm{TiO}_{2}$ [19], $\mathrm{CuO}$ [20] and $\mathrm{MgO}$ [21] have been widely studied as antibacterial agents. Among these particles, MgO nanoparticle is a unique metal oxide because it shows less toxicity towards hosts and compared to other metal oxide nanoparticles, it possesses various beneficial properties for biomedical applications including antibacterial activity [22,23].

Synthesis procedures play a significant role in attaining metal oxide nanoparticles with anticipated properties for a specific application [24,25]. There are various ways to synthesize metal oxide nanoparticles depending on the properties required for a particular application. Physical synthesis methods such as chemical vapor deposition [26], physical vapor deposition [27], laser ablation [28] and radio frequency magnetron sputtering [23,29] are commonly used in the metal oxide nanoparticle synthesis. Likewise, metal oxide nanoparticles are also prepared by chemical methods such as hydrothermal [30], wet-chemical [31], sol-gel [32], polyol [33] and microwave/ultrasound mediated chemical synthesis [34,35]. Both types of these synthesis methods have promising advantages, however, these synthesis methods involve expensive equipment and employ usage of hazardous chemicals which limits their application in the biomedical industry [36,37]. Thus, biosynthesis methods are preferred to synthesize nanoparticles for biomedical applications [38]. Three major biological organisms are involved in the biosynthetic nanoparticle preparation, namely bacteria [39], fungi [40] and plants [41]. Even though synthesis of nanoparticles via bacteria and fungi is potential for large scale nanoparticle synthesis with minimum usage of toxic chemicals [42-44], the extended production time is a stumbling block to its usage $[45,46]$. Hence, plant leaf extracts serves as an excellent medium to synthesize nanoparticle with controllable morphology and ability to enhance the 
downstream process of nanoparticle production [37]. There are only few reports available that supports the enhanced antibacterial activity of plant leaf extract mediated biosynthesized $\mathrm{MgO}$ nanoparticles [47-49]. Thus, the aim of the present work is to compare the antibacterial activity of $\mathrm{MgO}$ nanoparticles synthesized by three different leaf extracts towards gramnegative $E$. coli bacteria. The effects of nanoparticle characteristics such as size, morphology, concentration, surface charge and phytochemicals in influencing the antibacterial activity of $\mathrm{MgO}$ nanoparticles are also discussed.

\section{EXPERIMENTAL PROCEDURE}

\section{Synthesis and Characterization of MgO Nanoparticles}

The MgO nanoparticles were synthesized by using plant extracts namely Amaranthus tricolor, Amaranthus blitum and Andrographis paniculata. The aqueous plant extracts were prepared by adding fresh leaves of each plant, individually, with distilled water in the ration 1:10. The extracts were prepared by heating the mixture at $100{ }^{\circ} \mathrm{C}$ for $20 \mathrm{~min}$ and constantly mixing at $350 \mathrm{rpm}$ via magnetic stirrer (Cole-Parmer, Mumbai, India). Finally, the extracts were obtained by filtration using Whatman No. 1 filter paper to remove impurities and the pure extracts were stored at $4{ }^{\circ} \mathrm{C}$ in refrigerator for further use. The synthesis parameters were optimized and the nanoparticles were characterized using Dynamic light scattering (DLS) technique (Malvern, Singapore), UV-visible spectrometer (Perkin Elmer, Selangor, Malaysia), Fourier transform infrared (FTIR) spectroscopy (Mettler Toledo, Singapore) and Transmission electron microscopy (TEM) (Hitachi, Kuala Lumpur, Malaysia) to confirm their physicochemical characters such as size, surface charge, functional groups and morphology as reported in our previous study [50,51]. The physicochemical characteristics of $\mathrm{MgO}$ nanoparticles prepared from three distinct leaf extracts are shown in Table 1.

Table 1. Characteristics of leaf extract mediated biosynthesized MgO nanoparticles (Adapted and reproduced from [50] with permission from The Royal Society of Chemistry).

\begin{tabular}{|c|c|c|c|c|c|}
\hline $\begin{array}{l}\text { Sample } \\
\text { name }\end{array}$ & Precursor & Leaf extract & Size \pm PDI & Shape & $\begin{array}{l}\text { Surface } \\
\text { charge }\end{array}$ \\
\hline Sample NT & Magnesium & A. tricolor & $50 \pm 0.37$ & $\begin{array}{l}\text { Spherical and } \\
\text { hexagon }\end{array}$ & $-21.4 \mathrm{mV}$ \\
\hline Sample NB & nitrate & A. blitum & $78 \pm 0.35$ & Spherical & $-15.4 \mathrm{mV}$ \\
\hline Sample NP & & A. paniculata & $32 \pm 0.56$ & Spherical & $-11.4 \mathrm{mV}$ \\
\hline
\end{tabular}

* Sample NT-MgO nanoparticles prepared using magnesium nitrate and A. tricolor leaf extract, Sample $\mathrm{NB}-\mathrm{MgO}$ nanoparticles prepared using magnesium nitrate and A. blitum leaf extract, Sample NP-MgO nanoparticles prepared using magnesium nitrate and $A$. paniculata leaf extract. 


\section{Bacterial Culture}

The microorganism Escherichia coli (MTCC739) was obtained from Sigma-Aldrich (Selangor, Malaysia). In the present study, this strain was used to evaluate the inhibition ability of nanoparticles, as it is highly stable towards heavy metals compared to other strains. Most of the previously reported studies utilized this strain to evaluate the antibacterial activity of natural extracts against food borne pathogens [52,53]. In addition, it is noteworthy that the inhibition of this $E$. coli strain by a naturally extracted material demonstrates the capacity of the extract to inhibit growth of most E. coli stains $[54,55]$. The purchased bacterial cells were stored in a refrigerator at $-2{ }^{\circ} \mathrm{C} .2 .1 \% \mathrm{w} / \mathrm{v}$ of Mueller-Hinton broth purchased from Merck (Selangor, Malaysia) was dissolved in $50 \mathrm{~mL}$ of distilled water and was autoclaved at $121{ }^{\circ} \mathrm{C}$ for $15 \mathrm{~min}$. The bacterial cells were thawed at $25{ }^{\circ} \mathrm{C}$ and $1 \% \mathrm{v} / \mathrm{v}$ of bacteria was inoculated into the autoclaved broth under sterile condition. The broth with bacterial inoculum was incubated in a rotary shaking incubator for 30 hours at $30^{\circ} \mathrm{C}$ with $200 \mathrm{rpm}$.

\section{Antibacterial Activity}

The fully-grown bacterial cells in the broth medium were harvested by centrifugation at $25^{\circ} \mathrm{C}, 3500 \mathrm{rpm}$ for $5 \mathrm{~min}$. The supernatant was removed, and the cell pellet was washed for several times with distilled water. The bacteria was then transferred to Mueller-Hinton agar procured from Merck using spread plate technique [56]. The colloidal MgO nanoparticles were diluted with distilled water to analyze the effect of the concentration and dosage of the nanoparticles in inhibiting bacterial growth. Different dosages of $\mathrm{MgO}$ nanoparticles from three different leaf extracts were transferred to a sterile disc placed on the agar plate cultured with $E$. coli and the zone of inhibitions were measured after incubation at $30^{\circ} \mathrm{C}$ for 30 hours.

\section{Concentration and Dosage of Biosynthesized MgO Nanoparticles}

Since the MgO nanoparticles were synthesized by using different leaf extracts which possess distinct phytochemical compositions, the concentration of nanoparticles per unit volume varies from one to another. The concentration of $\mathrm{MgO}$ nanoparticles synthesized by leaf extracts were calculated using standard linear graph method (Origin 8 software). Spherical shaped chemically synthesized MgO nanoparticles [57] were used to obtain the $\mathrm{MgO}$ linear correlation graph. The linear equation $Y=0.3748 x+0.0511$ was obtained as the line of best fit from the graph displayed in Figure 1. The concentration and quantity of $\mathrm{MgO}$ nanoparticles prepared using leaf mediated biosynthesis method can be attained by substituting the respective absorbance at $322 \mathrm{~nm}$ in the linear equation. The concentration and quantity of $\mathrm{MgO}$ nanoparticle prepared by each leaf extract are listed in Table 2. Dosages ranging from 20 to $100 \mu \mathrm{L}$ of colloidal MgO nanoparticles were used in the study. 


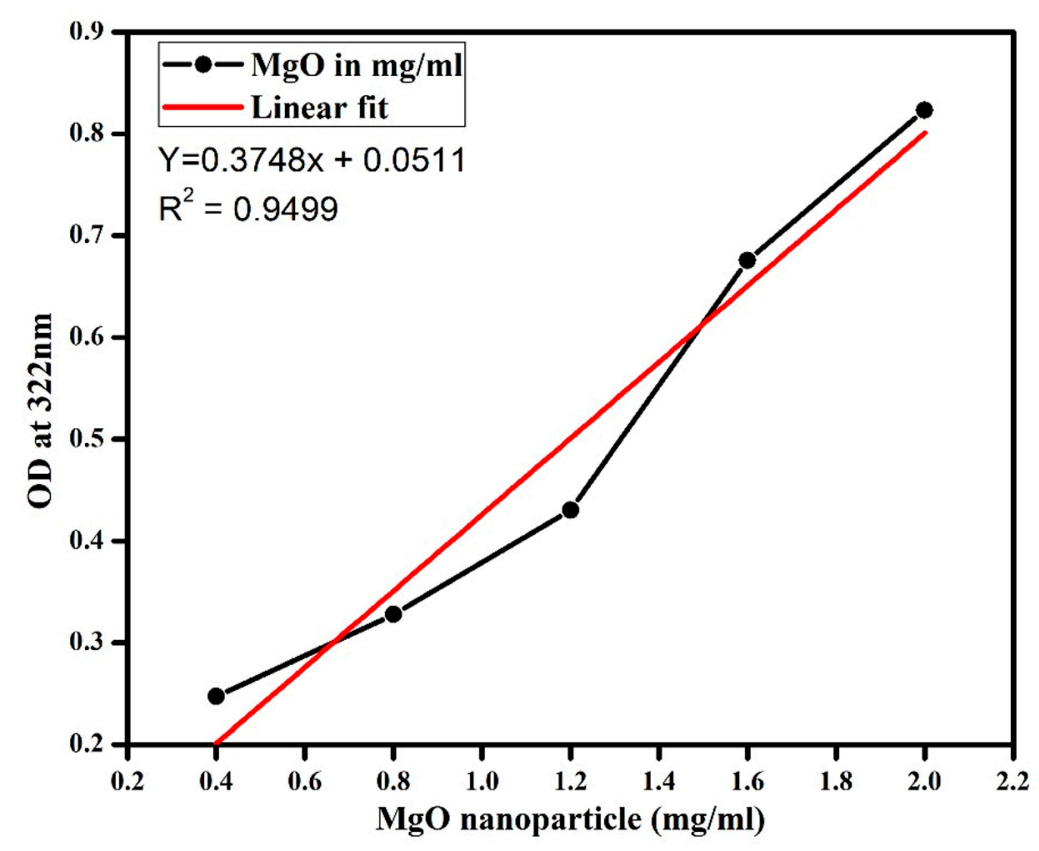

Figure 1. Standard linear graph of pure MgO nanoparticles to determine the concentration of colloidal MgO nanoparticles.

Table 2. Concentration of biosynthesized MgO nanoparticles via leaf extracts.

\begin{tabular}{ccc}
\hline Sample $^{*}$ & Absorbance at 322 $\mathbf{~ n m}$ & Concentration $\mathbf{( m g} / \mathbf{m L})$ \\
\hline Sample NT & $0.26 \pm 0.01$ & 0.56 \\
Sample NB & $0.39 \pm 0.015$ & 1.08 \\
Sample NP & $0.33 \pm 0.02$ & 0.82 \\
\hline
\end{tabular}

* Sample NT-MgO nanoparticles prepared using magnesium nitrate and A. tricolor leaf extract, Sample NB-MgO nanoparticles prepared using magnesium nitrate and A. blitum leaf extract, Sample NP-MgO nanoparticles prepared using magnesium nitrate and $A$. paniculata leaf extract. The concentrations were determined via experiments and analysis conducted in triplicate $(n=3)$ and error from the triplicate experiment were included as \pm standard deviation.

\section{RESULTS AND DISCUSSIONS}

\section{Dosage of MgO Nanoparticles}

The concentration of $\mathrm{MgO}$ nanoparticle present in each dosage which was prepared by using the three distinct leaf extracts as tabulated in Table 3. The yield of the nanoparticles depends on the crude phytochemicals extracted from the plants and this study aims at evaluating the antibacterial efficiency of crude phytochemical coated MgO nanoparticles. The dosages used in the study are reported as $\mu \mathrm{L}$ to compare the antibacterial activity of $\mathrm{MgO}$ nanoparticles from three different plant extracts which yields different concentration of MgO nanoparticles as mentioned in literature [58,59]. Thus, it is essential to note the concentration of nanoparticles present in each dosage of the samples as denoted in Table 3. 
Table 3. Concentration of $\mathrm{MgO}$ nanoparticles present in different dosages.

\begin{tabular}{cccc}
\hline \multirow{2}{*}{ Dosage $(\mu \mathrm{L})$} & \multicolumn{3}{c}{ Concentration of MgO nanoparticle $(\boldsymbol{\mu g} / \mathbf{m L})$} \\
\cline { 2 - 4 } & Sample NT & Sample NB & Sample NP * \\
\hline 20 & 11.2 & 21.6 & 16.4 \\
40 & 22.4 & 43.2 & 32.8 \\
60 & 33.6 & 64.8 & 49.2 \\
80 & 44.8 & 86.4 & 65.6 \\
100 & 56 & 108 & 82 \\
\hline
\end{tabular}

* Sample NT-MgO nanoparticles prepared using magnesium nitrate and A. tricolor leaf extract, Sample NB-MgO nanoparticles prepared using magnesium nitrate and A. blitum leaf extract, Sample NP-MgO nanoparticles prepared using magnesium nitrate and $A$. paniculata leaf extract.

\section{Antibacterial Activity of MgO Nanoparticles}

Figure 2A-C shows the antibacterial activity of $\mathrm{MgO}$ nanoparticles prepared using three different leaf extracts at different dosages (20-100 $\mu \mathrm{L})$ against a foodborne gram negative pathogen $E$. coli. It is evident as shown in Figure 2 that $\mathrm{MgO}$ nanoparticles possess antibacterial activity against E. coli based on the zone of inhibition. However, the zone of inhibition was found to be less compared to other literatures, the concentration of nanoparticles synthesized by using aqueous leaf extract were low [47,48,60-62]. Literature shows that chemically synthesized MgO nanoparticle at higher concentration $(<100 \mu \mathrm{g} / \mathrm{mL})$ exhibits strong antibacterial activity against food borne bacteria [60-62]. On the other hand, biosynthesized $\mathrm{MgO}$ nanoparticle activity against food borne bacteria were also reported in some literatures [47-49] to have a higher bacterial inhibiting concentration compared to the present work. The current result shows that the colloidal MgO nanoparticles exhibited a linear concentration related antibacterial activity rather than dosage related antibacterial effect. The zone of inhibition is lower than the previous reports as the concentration used in the present work was much lower than mentioned in the literatures and as colloidal $\mathrm{MgO}$ nanoparticles were used against the bacterial strains. It can be observed that there is no linear relation between dosage and antibacterial activity of $\mathrm{MgO}$ nanoparticles as depicted by the zone of inhibition measured in Figure 2. Sample NT and NB show concentration related increase in antibacterial activity of $\mathrm{MgO}$ nanoparticle up to $60 \mu \mathrm{L}$ dose whereas sample NP shows dosage dependent increase of antibacterial activity up to $80 \mu \mathrm{L}$ dosage. Subsequently, we observe a decrease in the zone of inhibition indicating a lower antibacterial activity at higher dosages. This may be due to bacteria resistance against a higher concentration of nanoparticles [63]. This may also be due to agglomeration when a higher concentration (dosage) of nanoparticles are added to the bacterial growth medium which then reduces the release of ROS that goes on to induce bacterial cell death and prevent their growth. Also noteworthy is that the zone of inhibition of sample NB at $60 \mu \mathrm{L}$ dosage towards $E$. coli is similar 
to the previous work in which $5 \mathrm{mg} / \mathrm{mL}$ of Aloe vera extract synthesized MgO nanoparticles were used [47]. However, $60 \mu \mathrm{L}$ dosage contains $64.8 \mu \mathrm{g} / \mathrm{mL}$ of $\mathrm{MgO}$ nanoparticles which is lower than the amount of nanoparticles used to inhibit bacteria in the previous work. Similarly, $100 \mu \mathrm{g} / \mathrm{mL}$ of rod shaped MgO nanoparticles synthesized via A. paniculata leaf extract showed enhanced zone of inhibition towards $E$. coli $(20 \mathrm{~mm})$ [48]. However, the present work shows that there is a higher antibacterial activity against $E$. coli for $\mathrm{MgO}$ nanoparticles synthesized via $A$. paniculata leaf extract at $80 \mu \mathrm{L}$ dosage $(11.6 \mathrm{~mm})$ which contains only $\sim 65 \mu \mathrm{g} / \mathrm{mL}$ of MgO nanoparticle.
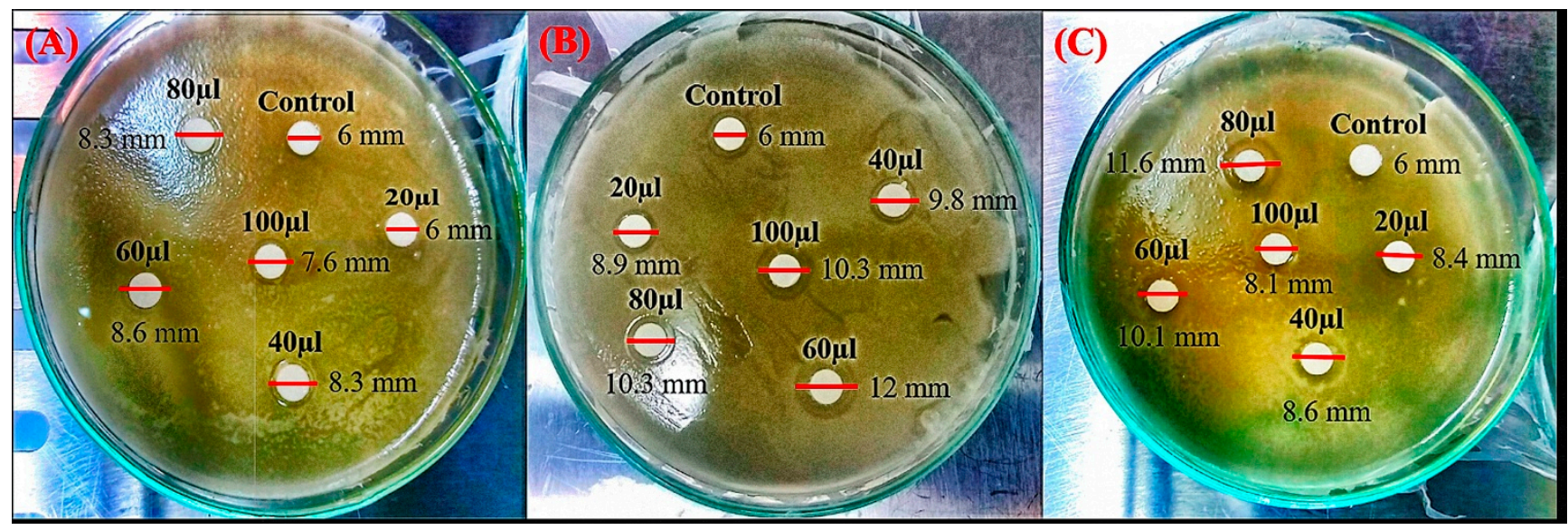

Figure 2. Representative images of three experiments for each sample: Zone of $E$. coli inhibition observed after treating with (A) sample NT, (B) sample NB and (C) sample NP. Sample NT-MgO nanoparticles prepared using magnesium nitrate and A. tricolor leaf extract, Sample NB-MgO nanoparticles prepared using magnesium nitrate and A. blitum leaf extract, Sample NP-MgO nanoparticles prepared using magnesium nitrate and A. paniculata leaf extract. The colloidal MgO nanoparticles were diluted with distilled water to analyze their antibacterial effect. Different dosages of three MgO nanoparticle samples were transferred to a sterile disc placed on the agar plate cultured with E. coli and the zone of inhibitions were measured after incubation at $30^{\circ} \mathrm{C}$ for 30 hours. Experiments were conducted in triplicate $(n=3)$.

\section{Comparative Antibacterial Activity of Three MgO Nanoparticles}

Figure 3 shows the antibacterial activity of $\mathrm{MgO}$ nanoparticles prepared in sample NT, NB and NP. It can be noted that both sample NB and NT showed better antibacterial activity at $60 \mu \mathrm{L}$ dosage, compared to sample NP. However, sample NB shows higher zone of inhibition (12 mm) at $60 \mu \mathrm{L}$ dosage compared to all the samples. Sample NP shows a distinct mechanism of antibacterial activity compared to other two samples and the highest zone of inhibition was found to be at $80 \mu \mathrm{L}$ dosage. This difference in the antibacterial mechanism may be due to the quantity of phytochemicals present in the leaf extract [38] or the nanoparticle concentration from leaf extract mediated synthesis [64]. It has been explained in literature that phytochemicals serve as the reducing and stabilizing agent for nanoparticle synthesis [38]. Thus, these phytochemicals are responsible for nanoparticle concentration in the colloidal solution [64] which is significant in the current study. Depending on the concentration, 
shape and size in each dosage, MgO nanoparticles exhibited dosage dependent antibacterial activity against $E$. coli bacteria. Also, it can be observed that the quantity of phytochemicals present in each of the leaf is different [65-72] and certain phytochemicals such as flavonoids, phenols and terpenoids possess antibacterial activity [73-75] which also contribute to the overall antibacterial mechanism of these biosynthesized MgO nanoparticles.

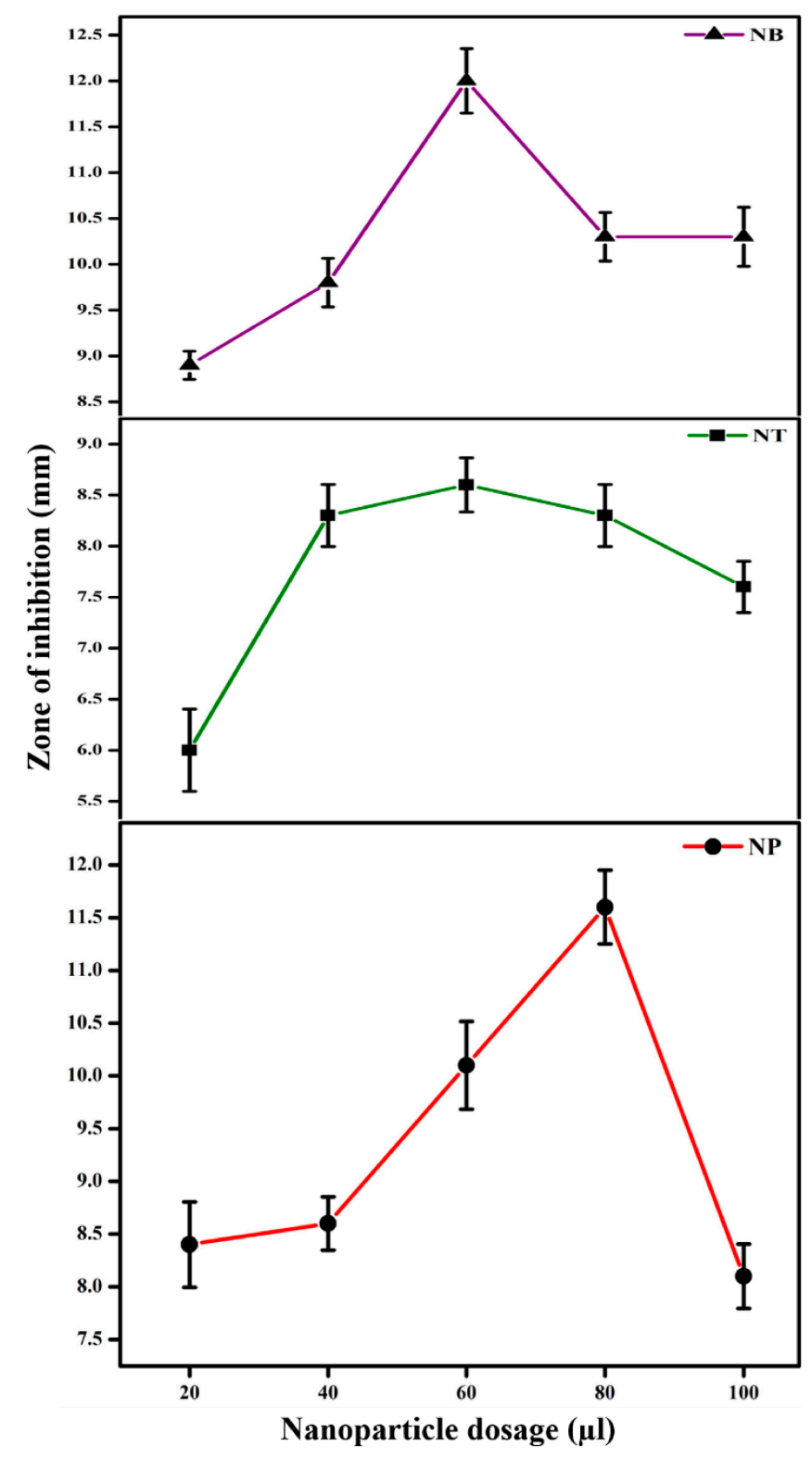

Figure 3. Comparative antibacterial activity of sample NT, NB and NP via disc diffusion method. Sample NT-MgO nanoparticles prepared using magnesium nitrate and A. tricolor leaf extract, Sample NB-MgO nanoparticles prepared using magnesium nitrate and A. blitum leaf extract, Sample NP-MgO nanoparticles prepared using magnesium nitrate and $A$. paniculata leaf extract. Experiments were conducted in triplicate $(n=3)$, and the error bars represent the standard deviation. Both sample NB and NT showed better antibacterial activity at $60 \mu \mathrm{L}$ dosage, compared to sample NP. 


\section{Antibacterial Mechanism of MgO Nanoparticles}

The novelty of this current study is in the utilization of heat energy catalyzed, aqueous leaf extract for the synthesis of $\mathrm{MgO}$ nanoparticles in the antibacterial activity against $E$. coli. The magnesium nitrate was used as the precursor for the synthesis of nanoparticles which also enhances the synthesis process due to their lower molecular mass compared to other reported precursors such as magnesium acetate and magnesium nitrate along with sodium hydroxide [50,76]. Since it is a heat based catalyzed process, phytochemicals present may be degraded and lead to a difference in the quantity of nanoparticle produced in the different MgO samples [77] as in the current study.

Antibacterial activity of metal oxide nanoparticles can be attributed to three major mechanisms namely disruption of cell wall via electrostatic attraction [78], generation of reactive oxygen species (ROS) [79] and disruption of cell organelles, nucleus or genetic material [80]. It can be noted that phytochemicals which act as a reducing and stabilizing agent for $\mathrm{MgO}$ nanoparticle also have the potential of inhibiting bacterial growth [81]. Based on the previous reports and current results, three possible antibacterial mechanisms of MgO nanoparticles have been postulated in this study as shown in Figure 4. Figure 4 is a conceptual representation of probable antibacterial mechanism of $\mathrm{MgO}$ nanoparticles based on literatures and no evidence has been provided in the present manuscript to support it. Mechanism 1 explains the degradation of MgO nanoparticles by extracellular bacterial enzymes thereby facilitating the release of ROS. Bacteria possess a tendency of reducing complex molecules into simple ions as a source of nutrients for its growth and reproduction [82]. The bacteria may release extracellular enzymes which reduces $\mathrm{MgO}$ nanoparticles into ions along with the phytochemicals which stabilizes the nanoparticles [83]. The reduced phytochemicals from nanoparticles also may possess certain level of antibacterial activity through ROS production [84]. Moreover, it is noteworthy from the literatures that most of the phytochemicals present in each leaf extract possess antibacterial activity. These phytochemicals include phenols, flavonoids, saponins, alkaloids, carotenoids, andrographolides, tannin and anthocyanidin, which may also contribute towards the antimicrobial activity of the $\mathrm{MgO}$ nanoparticles [77,85-87]. Along with phytochemicals, the oxygen ion released from $\mathrm{MgO}$ nanoparticle also leads to ROS production [88]. The magnesium ion released from the nanoparticle binds and enters into the bacterial cell via electrostatic attraction which damages bacterial cell membrane by reaction with sulfhydryl group $[79,89]$. The ROS production by oxygen ion, reduced phytochemicals and magnesium ion reaction with sulfhydryl group leads to the antibacterial activity of $\mathrm{MgO}$ nanoparticle according to mechanism 1 in Figure 4. 


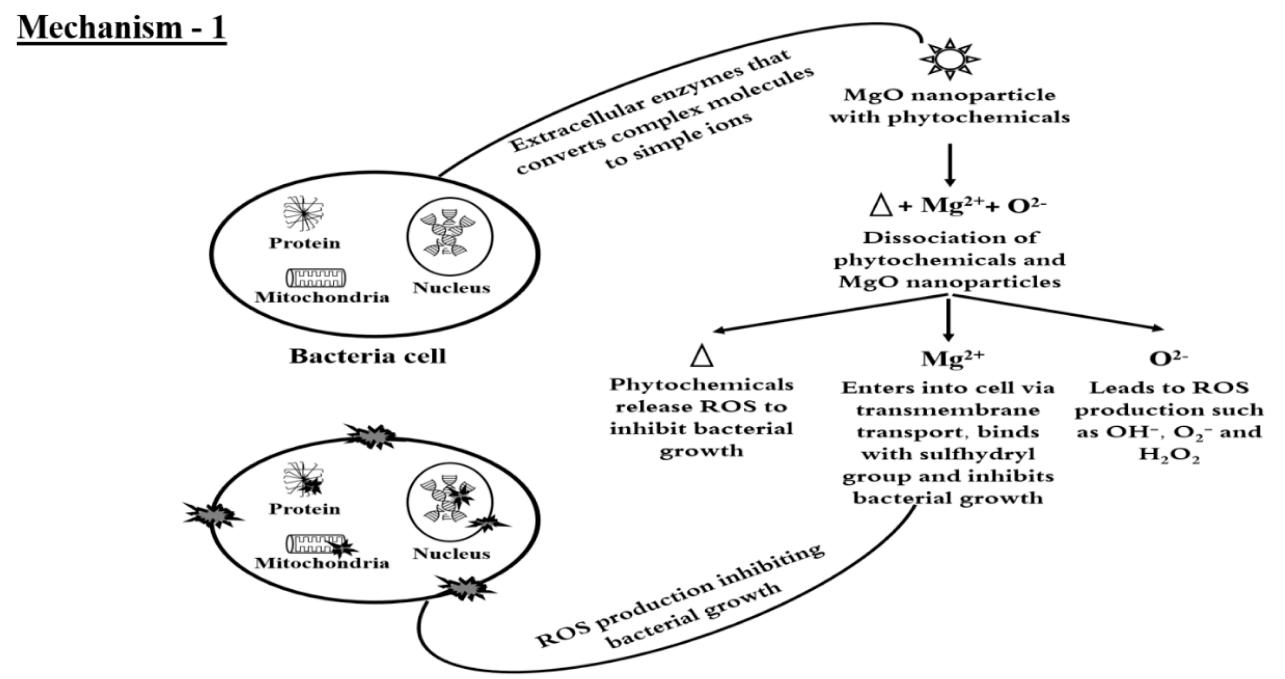

$\underline{\text { Mechanism - } 2}$

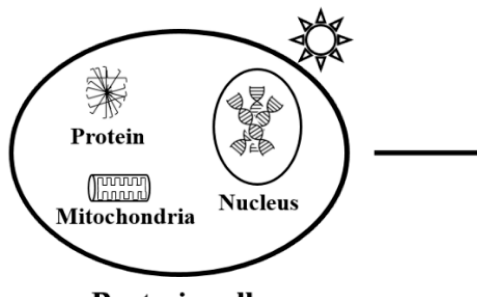

Bacteria cell

MgO nanoparticle binding with bacterial cell wall via electrostatic attraction

\section{Mechanism - 3}

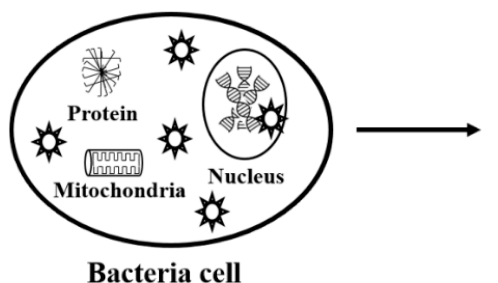

Bacteria cell

Entry of nanoparticle into the bacterial cell

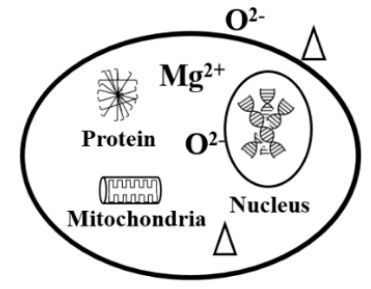

Nanoparticle dissociation via bacterial enzymes and entry of ions into bacterial cell

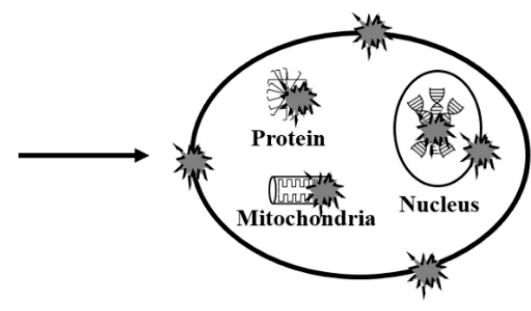

Disruption of bacterial cell wall and cell organelles by ROS production and $\mathrm{Mg}$ ion binding with sulfhydryl group

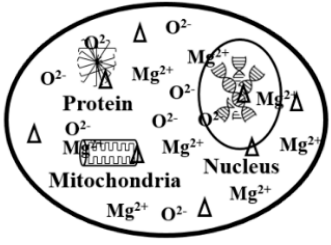

Dissociation of $\mathrm{MgO}$ nanoparticle via intracellular bacterial enzymes

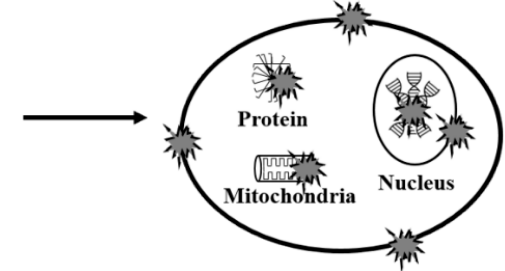

Intracellular ROS production inhibiting bacterial growth

Figure 4. Proposed antibacterial mechanisms of $\mathrm{MgO}$ nanoparticles synthesized using heat catalyzed leaf extracts. Mechanism-1: Degradation of MgO nanoparticles by extracellular bacterial enzymes and facilitates the release of ROS; Mechanism-2: Binding of MgO nanoparticle with bacterial cell wall through electrostatic attraction and follows mechanism-1; and Mechanism-3: Entry of MgO nanoparticle into bacterial cells, reduces into ions via intracellular bacterial enzymes, causes mortality to bacterial population and follows ROS production similar to mechanism 1.

On the other hand, the mechanism 2 in Figure 4 explains the binding of MgO nanoparticle with bacterial cell wall through electrostatic attraction [90] and follows the mechanism as stated in mechanism 1 . The probability of this antibacterial mechanism for $\mathrm{MgO}$ nanoparticle is low as the surface charge of both nanoparticles as shown in Table 1 [50] and cell surface are negative [91]. Mechanism 3 in Figure 4 explains the entry of MgO 
nanoparticle into bacterial cell [92], reduced into ions via intracellular bacterial enzymes and causes mortality to bacterial population [93] following ROS production similar to mechanism 1 . This mechanism may also be possible as the pore size of bacterial cell wall ranges in between 50$500 \mathrm{~nm}$ [94] while those of the MgO nanoparticles used in the current studies are between $30-80 \mathrm{~nm}$ size [77]. However, it was speculated that mechanism 1 may be the reason for antibacterial activity in the current study. This is because as the dosage increased, the antibacterial activity revealed that the extracellular bacterial enzymes slowly degraded the phytochemical stabilized $\mathrm{MgO}$ nanoparticles. The higher antibacterial activity at $60 \mu \mathrm{L}$ dosage of sample NT, NB and $80 \mu \mathrm{L}$ dosage of sample NP may be due to the effect of extracellular enzyme activity in degrading the nanoparticle and the phytochemicals that stabilizes the nanoparticles. However, the exact mechanism of leaf extract synthesized MgO nanoparticles is still unknown and will be explored by further studies against several foodborne pathogens. 2'-7'-Dichlorodihydrofluorescein diacetate (DCFH-DA) is a cell permeable fluorescent and chemiluminescent probe widely available for direct measurement of cellular redox state [95]. Other methods such as high performance liquid chromatography [96], capillary electrophoresis [97], luciferin derivative in conjunction with glutathione $S$-transferase enzyme and bimane compounds such as monobromobimane and monochlorobimane [98] were used to measure reduced glutathione and oxidized reduced glutathione levels in cells which indicate cellular oxidative stress via presence of reactive oxygen species [99].

\section{CONCLUSION}

The present study reveals the antibacterial activity of $\mathrm{MgO}$ nanoparticles synthesized by using three different leaf extracts. It can be noted that $\mathrm{MgO}$ nanoparticles sample from A. blitum leaf extract shows higher antibacterial activity towards $E$. coli at $60 \mu \mathrm{L} / \mathrm{mL}$ dosage. The concentration and dosage of $\mathrm{MgO}$ nanoparticles present in each sample was identified by using linear graph obtained by different concentration of chemically synthesized pure MgO nanoparticles. A comparison of the antibacterial activity of different leaf extract synthesized MgO nanoparticles were also carried out. Further experimental validation of the antimicrobial activity of $\mathrm{MgO}$ nanoparticles with phytochemicals as functional groups may involve the comparison of chemically synthesized $\mathrm{MgO}$ nanoparticles, purified MgO nanoparticles and leaf extract as a control. A conceptual antimicrobial mechanism of the $\mathrm{MgO}$ nanoparticles is also discussed. The proposed mechanism is based on the findings from the disc diffusion method of the present work and reported literature. Microscopic analysis to evaluate the antibacterial mechanism of $\mathrm{MgO}$ nanoparticles, mass spectroscopic analysis of the phytochemical-MgO nanoparticles to evaluate the functional moieties and flowcytometry analysis to evaluate the ROS produced by the nanoparticles will further 
validate the preliminary findings of this work. The current study will promote research into the antibacterial activity of $\mathrm{MgO}$ nanoparticles via leaf extract mediated synthesis and enable related applications as a potential antibacterial agent to control food borne pathogens.

\section{DATA AVAILABILITY}

The dataset of the study is available from the authors upon reasonable request.

\section{AUTHOR CONTRIBUTIONS}

JJ designed and performed the study. YSC analyzed the data and wrote the paper. MKD reviewed the manuscript and enhanced the discussion section.

\section{CONFLICTS OF INTEREST}

The authors declare that there is no conflict of interest.

\section{FUNDING}

No fund was received for this project.

\section{ACKNOWLEDGMENTS}

The authors wish to acknowledge Curtin University, Malaysia, for their financial support through the Curtin Sarawak Postgraduate Research Scholarship (CSPRS) scheme.

\section{REFERENCES}

1. Harrington R. Michigan notovirus outbreak is an example of a huge problem. Business Insider. 2016 Feb 18.

2. Bean NH, Griffin PM. Foodborne disease outbreaks in the United States, 19731987: pathogens, vehicles, and trends. J Food Prot. 1990;53(9):804-17.

3. Folster JP, Grass JE, Bicknese A, Taylor J, Friedman CR, Whichard JM. Characterization of Resistance Genes and Plasmids from Outbreaks and Illness Clusters Caused by Salmonella Resistant to Ceftriaxone in the United States, 2011-2012. Microb Drug Resist. 2017;23(2):188-93.

4. Butler MS, Blaskovich MA, Cooper MA. Antibiotics in the clinical pipeline at the end of 2015. J Antibiot. 2017;70(1):3.

5. Wright GD, Sutherland AD. New strategies for combating multidrug-resistant bacteria. Trends Mol Med. 2007;13(6):260-7.

6. de Sousa JM, Balbontín R, Durão P, Gordo I. Multidrug-resistant bacteria compensate for the epistasis between resistances. PLoS Biol. 2017;15(4):e2001741.

7. Mirhosseini M, Afzali M. Investigation into the antibacterial behavior of suspensions of magnesium oxide nanoparticles in combination with nisin and heat against Escherichia coli and Staphylococcus aureus in milk. Food Control. 2016;68:208-15. 
8. Campbell AL. Ceramic glaze having antimicrobial property. United States Patent US9434638. 2016 Sep 6.

9. Chauhan DS, Gopal CSA, Kumar D, Mahato N, Quraishi MA, Cho MH. Microwave induced facile synthesis and characterization of ZnO nanoparticles as efficient antibacterial agents. Mater Discov. 2018;11:19-25.

10. Mirhosseini M. Evaluation of antibacterial effect of magnesium oxide nanoparticles with nisin and heat in milk. Nanomed J. 2016;3(2):135-42.

11. Arakawa FS, Shimabuku-Biadola QL, Fernandes Silva M, Bergamasco R. Development of a new vacuum impregnation method at room atmosphere to produce silver-copper oxide nanoparticles on activated carbon for antibacterial applications. Environ Technol. 2019:1-12. doi: 10.1080/ 09593330.2019.1567607

12. Coelho CC, Araújo R, Quadros PA, Sousa SR, Monteiro FJ. Antibacterial bone substitute of hydroxyapatite and magnesium oxide to prevent dental and orthopaedic infections. Mater Sci Eng C. 2019;97:529-38.

13. Pugazhendhi A, Prabhu R, Muruganantham K, Shanmuganathan R, Natarajan S. Anticancer, antimicrobial and photocatalytic activities of green synthesized magnesium oxide nanoparticles (MgONPs) using aqueous extract of Sargassum wightii. J Photochem Photobiol B. 2019;190:86-97.

14. Siddiqi KS, Ur Rahman A, Husen A. Properties of zinc oxide nanoparticles and their activity against microbes. Nanoscale Res Lett. 2018;13(1):141.

15. El-Mekkawi DM, Selim MM, Hamdi N, Hassan SA, Ezzat A. Studies on the influence of the physicochemical characteristics of nanostructured copper, zinc and magnesium oxides on their antibacterial activities. J Environ Chem Eng. 2018;6(4):5608-15.

16. Song C, Sun W, Xiao Y, Shi X. Ultrasmall iron oxide nanoparticles: Synthesis, surface modification, assembly, and biomedical applications. Drug Discov Today. 2019;24(3):835-844.

17. Yang G, Phua SZF, Bindra AK, Zhao Y. Degradability and Clearance of Inorganic Nanoparticles for Biomedical Applications. Adv Mater. 2019;31(10):1805730.

18. Ba-Abbad MM, Takriff MS, Benamor A, Mahmoudi E, Mohammad AW. Arabic gum as green agent for ZnO nanoparticles synthesis: properties, mechanism and antibacterial activity. J Mater Sci Mater Electron. 2017;28(16): 12100-7.

19. Senarathna U, Fernando S, Gunasekara T, Weerasekera M, Hewageegana H, Arachchi N, et al. Enhanced antibacterial activity of $\mathrm{TiO}_{2}$ nanoparticle surface modified with Garcinia zeylanica extract. Chem Cent J. 2017;11(1):7.

20. Sugirdha S, Pandurangan D, Arun Y, Karthikeyan K, Chandrasekar P. Solventfree implementation of two dissimilar reactions using recyclable $\mathrm{CuO}$ nanoparticle under ball-milling conditions: Synthesis of new oxindoletriazole pharmacophores. Green Chem. 2017;19(15):3601-10.

21. Cai Y, Li C, Wu D, Wang W, Tan F, Wang X, et al. Highly active MgO nanoparticles for simultaneous bacterial inactivation and heavy metal removal from aqueous solution. Chem Eng J. 2017;312:158-66. 
22. Jeevanandam J, Danquah MK, Debnath S, Meka VS, Chan YS. Opportunities for nano-formulations in type 2 diabetes mellitus treatments. Curr Pharm Biotechnol. 2015;16(10):853-70.

23. Abubakar D, Ahmed NM, Mahmud S, Algadri NA. Properties of NiO nanostructured growth using thermal dry oxidation of nickel metal thin film for hydrogen gas sensing at room temperature. Mater Res Express. 2017;4(7):075009.

24. Rao JP, Geckeler KE. Polymer nanoparticles: preparation techniques and sizecontrol parameters. Prog Polym Sci. 2011;36(7):887-913.

25. Jeevanandam J, Chan YS, Danquah MK. Nano-formulations of drugs: recent developments, impact and challenges. Biochimie. 2016;128:99-112.

26. Zhang Z, Wei B, Ajayan P. Self-assembled patterns of iron oxide nanoparticles by hydrothermal chemical-vapor deposition. Appl Phys Lett. 2001;79(25): 4207-9.

27. Lyu SC, Zhang Y, Lee CJ, Ruh H, Lee HJ. Low-temperature growth of ZnO nanowire array by a simple physical vapor-deposition method. Chem Mater. 2003;15(17):3294-9.

28. Sasaki T, Shimizu Y, Koshizaki N. Preparation of metal oxide-based nanomaterials using nanosecond pulsed laser ablation in liquids. J Photochem Photobiol A. 2006;182(3):335-41.

29. Minami T, Nanto H, Takata S. Highly conductive and transparent aluminum doped zinc oxide thin films prepared by RF magnetron sputtering. Jpn J Appl Phys. 1984;23(5A):L280.

30. Anikeev VI. Hydrothermal synthesis of metal oxide nanoparticles. In: Proceedings of XIII International science and technology conference, Hightech chemical technologies-2010 with elements of Scientific school for young people innovation in chemistry; 2010 Jun 29-Jul 2; Ivanovo, Russia. Ivanovo (Russia): GOUVPO Ivan Gos Khim-Tekhnol Un-t; 2010. p. 46.

31. Maaz K, Mumtaz A, Hasanain S, Ceylan A. Synthesis and magnetic properties of cobalt ferrite $\left(\mathrm{CoFe}_{2} \mathrm{O}_{4}\right)$ nanoparticles prepared by wet chemical route. J Magn Magn Mater. 2007;308(2):289-95.

32. Niederberger M. Nonaqueous sol-gel routes to metal oxide nanoparticles. Acc Chem Res. 2007;40(9):793-800.

33. Feldmann C, Jungk HO. Polyol-mediated preparation of nanoscale oxide particles. Angew Chem Int Ed. 2001;40(2):359-62.

34. Polychronopoulou K, Zedan AF, Katsiotis M, Baker M, AlKhoori A, AlQaradawi SY, et al. Rapid microwave assisted sol-gel synthesis of $\mathrm{CeO}_{2}$ and $\mathrm{Ce}_{\mathrm{x}} \mathrm{Sm}_{1-\mathrm{x}} \mathrm{O}_{2}$ nanoparticle catalysts for CO oxidation. Mol Catal. 2017;428:41-55.

35. Kumar RV, Diamant Y, Gedanken A. Sonochemical synthesis and characterization of nanometer-size transition metal oxides from metal acetates. Chem Mater. 2000;12(8):2301-5.

36. Kharissova OV, Dias HR, Kharisov BI, Pérez BO, Pérez VMJ. The greener synthesis of nanoparticles. Trends Biotechnol. 2013;31(4):240-8.

37. Jeevanandam J, Chan YS, Danquah MK. Biosynthesis of metal and metal oxide nanoparticles. ChemBioEng Rev. 2016;3(2):55-67. 
38. Iravani S. Green synthesis of metal nanoparticles using plants. Green Chem. 2011;13(10):2638-50.

39. Fariq A, Khan T, Yasmin A. Microbial synthesis of nanoparticles and their potential applications in biomedicine. J Appl Biomed. 2017;15(4):241-8.

40. Manimaran M, Kannabiran K. Actinomycetes mediated biogenic synthesis of metal and metal oxide nanoparticles: Progress and challenges. Lett Appl Microbiol. 2017;64(6):401-8.

41. Ahmed S, Chaudhry SA, Ikram S. A review on biogenic synthesis of ZnO nanoparticles using plant extracts and microbes: A prospect towards green chemistry. J Photochem Photobiol B. 2017;166:272-84.

42. Thakkar KN, Mhatre SS, Parikh RY. Biological synthesis of metallic nanoparticles. Nanomedicine. 2010;6(2):257-62.

43. Iravani S. Bacteria in nanoparticle synthesis: current status and future prospects. Int Scholarly Res Not. 2014;2014:359316.

44. Hulkoti NI, Taranath T. Biosynthesis of nanoparticles using microbes-a review. Colloids Surf B. 2014;121:474-83.

45. Narayanan KB, Sakthivel N. Biological synthesis of metal nanoparticles by microbes. Adv Colloid Interface Sci. 2010;156(1):1-13.

46. Mukherjee P, Ahmad A, Mandal D, Senapati S, Sainkar SR, Khan MI, et al. Fungus-mediated synthesis of silver nanoparticles and their immobilization in the mycelial matrix: a novel biological approach to nanoparticle synthesis. Nano Lett. 2001;1(10):515-9.

47. Umaralikhan L, Jaffar MJM. Green Synthesis of MgO Nanoparticles and it Antibacterial Activity. Iran J Sci Technol A. 2018;42(2):477-85.

48. Karthik K, Dhanuskodi S, Gobinath C, Sivaramakrishnan S. Microwave Assisted Green Synthesis of MgO Nanorods and Their Antibacterial and Antibreast Cancer Activities. Mater Lett. 2017;206:217-20.

49. Sharma G, Soni R, Jasuja ND. Phytoassisted synthesis of magnesium oxide nanoparticles with Swertia chirayaita. J Taibah Univ Sci. 2017;11(3):471-7.

50. Jeevanandam J, Chan YS, Danquah MK. Biosynthesis and characterization of MgO nanoparticles from plant extracts via induced molecular nucleation. New J Chem. 2017;41:2800-14.

51. Jeevanandam J, Chan YS, Danquah MK. Effect of $\mathrm{pH}$ variations on morphological transformation of biosynthesized MgO nanoparticles. Part Sci Technol. 2019; doi: 10.1080/02726351.2019.1566938.

52. Chatterjee SK, Bhattacharjee I, Chandra G. Bactericidal activities of some common herbs in India. Pharm Biol. 2007;45(5):350-4.

53. Natarajan D, Srinivasan R, Shivakumar MS. Phyllanthus wightianus Müll. Arg.: a potential source for natural antimicrobial agents. BioMed Res Int. 2014;2014:135082.

54. Pandey A, Singh P. Antibacterial activity of Syzygium aromaticum (clove) with metal ion effect against food borne pathogens. Asian J Plant Sci Res. 2011;1(2):69-80.

55. Laishram SK, Nath DR, Bailung B, Baruah I. In vitro antibacterial activity of essential oil from rhizome of homalomena aromatica against pathogenic bacteria. J Cell Tissue Res. 2006;6(2):849-51. 
56. Padmavathy N, Vijayaraghavan R. Enhanced bioactivity of ZnO nanoparticles-an antimicrobial study. Sci Technol Adv Mater. 2008;9(3):035004.

57. Jeevanandam J, Chan YS, Danquah MK. Calcination-Dependent Morphology Transformation of Sol-Gel-Synthesized MgO Nanoparticles. ChemistrySelect. 2017;2(32):10393-404.

58. Shehzad A, Qureshi M, Jabeen S, Ahmad R, Alabdalall AH, Aljafary MA, et al. Synthesis, characterization and antibacterial activity of silver nanoparticles using Rhazya stricta. PeerJ. 2018;6:e6086.

59. Karaman DŞ, Manner S, Fallarero A, Rosenholm JM. Current approaches for exploration of nanoparticles as antibacterial agents. In: Kumavath R, editor. Antibacterial Agents. London (UK): IntechOpen; 2017.

60. Al-Hazmi F, Alnowaiser F, Al-Ghamdi A, Al-Ghamdi AA, Aly M, Al-Tuwirqi RM, et al. A new large-Scale synthesis of magnesium oxide nanowires: Structural and antibacterial properties. Superlattices Microstruct. 2012;52(2):200-9.

61. Sundrarajan M, Suresh J, Gandhi RR. A comparative study on antibacterial properties of $\mathrm{MgO}$ nanoparticles prepared under different calcination temperature. Dig J Nanomater Biostruct. 2012;7(3):983-9.

62. Jin T, He Y. Antibacterial activities of magnesium oxide (MgO) nanoparticles against foodborne pathogens. J Nanopart Res. 2011;13(12):6877-85.

63. Leung $\mathrm{YH}, \mathrm{Xu} \mathrm{X}$, Ma AP, Liu F, Ng AM, Shen Z, et al. Toxicity of $\mathrm{ZnO}$ and $\mathrm{TiO}_{2}$ to Escherichia coli cells. Sci Rep. 2016;6:35243.

64. Elemike EE, Onwudiwe DC, Ekennia AC, Katata-Seru L. Biosynthesis, characterization, and antimicrobial effect of silver nanoparticles obtained using Lavandula× intermedia. Res Chem Intermed. 2017;43(3):1383-94.

65. Rao KN, Padhy SK, Dinakaran SK, Banji D, Madireddy S, Avasarala H. Study of pharmacognostic, phytochemical, antimicrobial and antioxidant activities of Amaranthus tricolor Linn. leavs extract. Iran J Pharm Sci. 2010;6:289-99.

66. Fernando T, Bean G. Fatty acids and sterols of Amaranthus tricolor L. Food Chem. 1984;15(3):233-7.

67. Piattelli M, De Nicola MG, Castrogiovanni V. Photocontrol of amaranthin synthesis in Amaranthus tricolor. Phytochemistry. 1969;8(4):731-6.

68. Achigan-Dako EG, Sogbohossou OE, Maundu P. Current knowledge on Amaranthus spp.: research avenues for improved nutritional value and yield in leafy amaranths in sub-Saharan Africa. Euphytica. 2014;197(3):303-17.

69. Akowuah G, Zhari I, Mariam A. Analysis of urinary andrographolides and antioxidant status after oral administration of Andrographis paniculata leaf extract in rats. Food Chem Toxicol. 2008;46(12):3616-20.

70. Hossain MS, Urbi Z, Sule A, Rahman K. Andrographis paniculata (Burm. f.) Wall. ex Nees: a review of ethnobotany, phytochemistry, and pharmacology. Sci World J. 2014;2014:274905.

71. Siripong P, Kongkathip B, Preechanukool K, Picha P, Tunsuwan K, Taylor W. Cytotoxic diterpenoid constituents from Andrographis paniculata Nees leaves. J Sci Soc Thai. 1992;18(4):187-94.

72. Gupta K, Taneja S, Dhar K, Atal C. Flavonoids of Andrographis paniculata. Phytochemistry. 1983;22(1):314-5. 
73. Cushnie TT, Lamb AJ. Antimicrobial activity of flavonoids. Int J Antimicrob Agents. 2005;26(5):343-56.

74. $\mathrm{Fu} \mathrm{L}, \mathrm{Lu} \mathrm{W}$, Zhou X. Phenolic Compounds and In Vitro Antibacterial and Antioxidant Activities of Three Tropic Fruits: Persimmon, Guava, and Sweetsop. Biomed Res Int. 2016;2016:4287461.

75. Ocloo A, Nwokolo NC, Dayie NT. Phytochemical characterization and comparative efficacies of crude extracts of Carica papaya. Int J Drug Res Technol. 2017;2(5):6.

76. Palanisamy G, Pazhanivel T. Green synthesis of $\mathrm{MgO}$ nanoparticles for antibacterial activity. Int Res J Eng Technol. 2017;4:137-41.

77. Jeevanandam J, San Chan Y, Danquah MK. Biosynthesis and characterization of MgO nanoparticles from plant extracts via induced molecular nucleation. New J Chem. 2017;41(7):2800-14.

78. Ding X, Yuan P, Gao N, Zhu H, Yang YY, Xu QH. Au-Ag core-shell nanoparticles for simultaneous bacterial imaging and synergistic antibacterial activity. Nanomedicine. 2017;13(1):297-305.

79. Karthik K, Dhanuskodi S, Gobinath C, Sivaramakrishnan S. Microwaveassisted synthesis of CdO-ZnO nanocomposite and its antibacterial activity against human pathogens. Spectrochim Acta A Mol Biomol Spectrosc. 2015;139:7-12.

80. Hajipour MJ, Fromm KM, Ashkarran AA, de Aberasturi DJ, de Larramendi IR, Rojo T, et al. Antibacterial properties of nanoparticles. Trends Biotechnol. 2012;30(10):499-511.

81. Halilu M, Muhammad I, Dangoggo S, Farouq A, Ahmed A, Shamsuddeen A, et al. Phytochemical and antibacterial screening of petroleum ether and ethanol extracts of Sida cordifolia leaves. J Chem Society Nigeria. 2016;41(2):137-42.

82. Allison SD, Vitousek PM. Responses of extracellular enzymes to simple and complex nutrient inputs. Soil Biology and Biochemistry. 2005;37(5):937-44.

83. Cao Y, Xie Y, Liu L, Xiao A, Li Y, Zhang C, et al. Influence of phytochemicals on the biocompatibility of inorganic nanoparticles: a state-of-the-art review. Phytochem Rev. 2017;16(3):555-63.

84. Kumar S, Pandey AK. Chemistry and biological activities of flavonoids: an overview. Sci World J. 2013;2013:162750.

85. Alghazeer R, Elmansori A, Sidati M, Gammoudi F, Azwai S, Naas H, et al. In Vitro Antibacterial Activity of Flavonoid Extracts of Two Selected Libyan Algae against Multi-Drug Resistant Bacteria Isolated from Food Products. J Biosci Med. 2017;5:26-48.

86. Jiménez-Aguilar DM, Grusak MA. Minerals, vitamin C, phenolics, flavonoids and antioxidant activity of Amaranthus leafy vegetables. J Food Compost Anal. 2017;58:33-9.

87. Banerjee M, Parai D, Chattopadhyay S, Mukherjee SK. Andrographolide: antibacterial activity against common bacteria of human health concern and possible mechanism of action. Folia Microbiol. 2017;62(3):237-44.

88. Krishnamoorthy K, Manivannan G, Kim SJ, Jeyasubramanian K, Premanathan M. Antibacterial activity of MgO nanoparticles based on lipid peroxidation by oxygen vacancy. J Nanopart Res. 2012;14(9):1063. 
89. Karthik K, Dhanuskodi S, Gobinath C, Prabukumar S, Sivaramakrishnan S. Andrographis paniculata extract mediated green synthesis of $\mathrm{CdO}$ nanoparticles and its electrochemical and antibacterial studies. J Mater Sci. 2017;28(11):7991-8001.

90. Huang G, Ng TW, An T, Li G, Wang B, Wu D, et al. Interaction between bacterial cell membranes and nano- $\mathrm{TiO}_{2}$ revealed by two-dimensional FTIR correlation spectroscopy using bacterial ghost as a model cell envelope. Water Res. 2017;118:104-13.

91. Van Loosdrecht M, Lyklema J, Norde W, Schraa G, Zehnder A. Electrophoretic mobility and hydrophobicity as a measured to predict the initial steps of bacterial adhesion. Appl Environ Microbiol. 1987;53(8):1898-901.

92. Ren G, Hu D, Cheng EW, Vargas-Reus MA, Reip P, Allaker RP. Characterisation of copper oxide nanoparticles for antimicrobial applications. Int J Antimicrob Agents. 2009;33(6):587-90.

93. Newase S, Bankar A. Synthesis of bio-inspired Ag-Au nanocomposite and its anti-biofilm efficacy. Bulletin Mat Sci. 2017;40(1):157-62.

94. Meroueh SO, Bencze KZ, Hesek D, Lee M, Fisher JF, Stemmler TL, et al. Threedimensional structure of the bacterial cell wall peptidoglycan. Proc Natl Acad Sci U S A. 2006;103(12):4404-9.

95. Eruslanov E, Kusmartsev S. Identification of ROS using oxidized DCFDA and flow-cytometry. Methods Mol Biol. 2010;594:57-72.

96. Jones DP. Redox potential of GSH/GSSG couple: Assay and biological significance. Methods Enzymol. 2002;348:93-112.

97. Camera E, Picardo M. Analytical methods to investigate glutathione and related compounds in biological and pathological processes. J Chromatogr B. 2002;781(1):181-206.

98. Radkowsky AE, Kosower EM. Bimanes. 17. (Haloalkyl)-1,5-diazabicyclo[3.3.0] octadienediones (halo-9,10-dioxabimanes): reactivity toward the tripeptide thiol, glutathione. J Am Chem Soc. 1986;108(15):4527-31.

99. Held P. An introduction to reactive oxygen species measurement of ROS in cells. Winooski (VT, US): BioTek Instruments Inc.; 2012.

How to cite this article:

Jeevanandam J, Chan YS, Danquah MK. Evaluating the Antibacterial Activity of MgO Nanoparticles Synthesized from Aqueous Leaf Extract. Med One. 2019;4:e190011. https://doi.org/10.20900/mo.20190011 